\title{
Good Environmental Governance through the Inovation of Solid Waste Management in the Community of Gili Ketapang Island Kabupaten Probolinggo
}

\section{Resha Dwi Ayu Pangesti Mulyono}

University of Jember

\section{Abstract}

The problem of coastal area of Gili Ketapang Island is the accumulation of solid waste waste volume which causes environmental pollution due to the lack of public awareness. The writing of this article aims to link the synergy of good environmental governance with solid waste management through the application of Sound Material-

Corresponding Author: Resha Dwi Ayu Pangesti Mulyono

reshadwiayu.feb@unej.ac.id

Received: 7 August 2018 Accepted: 15 September 2018 Published: 22 October 2018

Publishing services provided by Knowledge

(c) Resha Dwi Ayu Pangesti Mulyono. This article is

distributed under the terms of

the Creative Commons

Attribution License, which

permits unrestricted use and redistribution provided that the original author and source are credited.

Selection and Peer-review under the responsibility of the ICE-BEES 2018 Conference Committee.

\section{G OPEN ACCESS}

Cycle Society concept. The research method used qualitative research type which was described in description. To dig information using direct interview techniques and documentation. The result of the research explains that there is a need for synergy between the government, society and private parties to manage solid waste in order to realize the environment of Gili Ketapang Island which is clean and beautiful so that the welfare of society can be realized.

Keywords: Good Environmental Governance, Sound Material-Cycle Society, Gili Ketapang Island

\section{Introduction}

Since long ago Indonesia has been known as the Maritime Country, where the sea area of Indonesia can surround the archipelagic state. As an archipelagic country, Indonesia has been internationally recognized (UNCLOS, 1982) which was then ratified by Indonesia with Law no. 17 In 1985. Under UNCLOS 1982, the total area of the Indonesian sea is 5.9 million km2, consisting of 3.2 million km2 territorial waters and $2.7 \mathrm{~km} 2$ waters of Exclusive Economic Zone, the area does not include the continental shelf. Coastal management is important to prioritize, this is because $60 \%$ of Indonesians live in coastal areas. Administratively, 42 cities and 181 districts are located in coastal areas. In the event of damage in the coastal areas, it will have an impact on coastal 
life and urban populations who generally consume fish. About $85 \%$ of fish resources come from coastal waters. Another impact is millions of workers, especially fishermen will lose their livelihood. The marine sector absorbs more than 16 million workers directly but $25 \%$ still contains the poor in coastal areas of Indonesia. In addition, the contribution of the marine and fisheries sector to GDP in the range of $30 \%$. According to data from the Economic and Industrial Committee (2016) the contribution is still low compared to Japan or Norway which has reached above 30 percent. Therefore, Indonesia needs to catch up from Japan.From all the mangrove forest and coral reefs in the world, about 30\% are in coastal areas of Indonesia.

Ecologically coastal area is actually a potential provider of Natural Resources, ie as a fish resource, mangroves, coral reefs, corals and so forth. Mangrove and coral reefs are very big role in maintaining the balance of coastal habitat. Providers of life support services, namely as a source of clean water, a place of cultivation. Provider of leisure services, as a place of recreation and tourism development. Recipient of waste, as a container of waste from activities on land and sea. Another important issue in the coastal region is the threat of rising sea levels of 1.1 meters in 2010. This sea level rise will result in the loss of 90,260 square kilometers of coastal areas with potential economic losses of US $\$ 25.56$ billion.

One of the problems that occurred was in the coastal area of Gili Ketapang village Sumber Asih sub-district of Probolinggo or better known as Gili Island. The distance to be taken approximately 10-15 kilometers by boat or about 45 minutes by sea travel from the port of tanjung tembagas which is the old port in Probolinggo district with big waves. Around the beginning of 1991 migrants began to arrive to the island of Gili with most of the livelihood of most fishermen because the grounds of the origin of the area of Sampang did not succeed and try luck in an island so that the majority of the population is Madurese and the majority were Muslim. According to Central Bureau of Statistics Probolinggo regency, the composition of native coastal areas of Gili Ketapang Island is 4,258 for men and 4,422 for women or totaling 8,680 with the number of households about 2,893 (BPS, 2016).

Factors leading to limited knowledge of managing and maintaining environmental hygiene, lack of hygiene aids from the Government and the limitation of community empowerment result in the volume of garbage that accumulates. The lack of awareness of the coastal community of Gili Ketapang Island towards hygiene especially on solid waste such as plastic, wood, cloth, organic, heavy metal, eggshell, paper and solid waste of the same kind still need to be improved so that the surrounding 
community is healthier and have cleaner area. Not only that, the coastal community of Gili Ketapang Island, whose majority have goat farming, is in a very poor condition, where the goats eat solid waste which is disposed of around the residential area plus waste of dirt carelessly. Sometimes solid waste 888 solids in particular can not be managed optimally and sometimes drifted by sea water or not. In general, the problems that occur in the coastal communities of Indonesia is the management and technical problems that come from land and sea. Like the case experienced by the coastal community of Gili Ketapang Island is the management of the region has not been implemented integratedly or still sectoral.

The lack of attention of the stakeholders in the closed state of society makes the implementation of planned programs less likely to be inhibited, in addition to limited access often not proclaimed in the strategic plan of coastal management as well as attention to solid waste management. Waste management issues must be handled seriously by synergizing between governments, academics, investors and other stakeholders by applying Good Enviromental Governance to every coastal community activity including solid waste processing using the latest technology. The public interest towards the potential of Gili Ketapang Island tourism continues to increase, it must be responded immediately considering Gili Ketapang Island becomes a new tourist destination that can increase Revenue of Probolinggo Regency.

If the bad habits of the coastal community of Gili Ketapang Island cannot be minimized then one can result in a decrease in the quality of life of the community and the unhealthy surrounding environment. The dispersion of pollutants from solid wastes especially heavy metals in waters by deposition processes will affect the life cycle of aquatic animals especially. So the purpose of writing this article is to provide advice through ideas by applying synergy between Good Envrionmental Governance through the role of Local Government by innovating solid waste management so that the coastal community of Gili Island can live cleaner, prosperous and protected from danger that threaten at any time by inviting all stakeholders to build coastal area of Gili Ketapang Island become more healthy and clean. This can also have an impact on increasing coastal tourist attraction of Gili Ketapang Island. The use of this governance concept invites us to put forward the interaction patterns of the parties concerned, not just the efficiency or effectiveness of its work just like in the management concept. 


\section{Literature Review}

\subsection{Good environmental governance}

Kotchen and Young (2006) stated that, "Governance systems can be considered as institutional filters, mediating between human actions and biophysical processes". According to them governance can be used to filter and mediate relationships between human activities and the environment. In the use of this governance concept, the Governance system must work to produce the three main groups that now interact with each other to the environment, namely the state, society, and the private sector. The concept of governance in the environment or can be called the environmental governance, see the state and society as an object as well as the subject of environmental conservation efforts. The state as an organization that has control over resources and power, has the ability to change natural conditions on a massive scale. Therefore, the fate of the environment is largely determined by the ability to discipline state behavior to be consistent with ecological principles. Through this governance concept, environmental governance is understood as the framework of state management in the framework of environmental management through its interaction with its people. But keep in mind that the role of the state here is to ascertain the direction and degree of change in accordance with what the ecosystem can tolerate, not the state's ability to change the bio-physical conditions.

Purwo (2008) The concept of environmental governance needs to be built on a central premise that social systems and ecosystems from time to time engage in interaction (action-reaction) that ends. The intergroup interaction that develops in the concept of governance has made the relationship between state, society, and private stands parallel. Governance on the concept of environmental governance is used in the need to understand and manage the interrelationships between social systems and ecosystems. Moreover, the management of social systems needs to be managed by promoting ecological values, and on the contrary, ecosystem resilience can be maintained through the management of social systems guided by ecological principles.

The use of the concept of governance in the environment has made the values that exist in governance are also applied and adapted to the interests of the environment. On that basis, the United Nations Development Program (UNDP), the United 
Nations Environment Program (UNEP), the World Bank, and the World Resources Institute mentioned in its publication entitled "A Guide to World Resources", there are seven elements of environmental governance. The seven elements are as follows.

1. Institutions and laws. Who makes and enforces regulations to use natural resources? What are the rules and laws when the rules are violated? Who will decide if there is a dispute?

2. The rights of participation and representation. How can the public influence or advocate for regulations on natural resources? Who will represent those who use or depend on natural resources when policies on natural resources are made?

3. Level of authority. At what level or scale: local, regional, national, international, authority over natural resources are located?

4. Accountability and transparency. How can those who supervise and manage natural resources can answer for the policies they make and to whom? How is the policy-making process open for review?

5. Property rights and position. Who owns a natural resource or has a legal right to supervise?

6. Market and financial flow. How do financial practices, economic policies and market behavior affect the authority over natural resources?

7. Science and risk. How ecology and social sciences are incorporated into natural resource policies are used to reduce risks to communities and ecosystems and to identify new opportunities?

In addition to the seven elements mentioned in "A Guide to World Resources", in relation to good environmental governance efforts, the Indonesian Center for Environmental Law (ICEL) also mentions that there are several criteria that must be integrated in any policies that have the urgency to realize the development policy of environment-oriented associated with various things, ie:

1. Empowerment, community involvement and public access to information

2. Transparency

3. Democratic decentralization

4. Recognition of the ecosystem and sustainable carrying capacity 
5. Recognition of indigenous peoples and local communities

6. Consistency and harmonization

7. Clarity, and

8. Power enforcement.

\section{Research Method}

In this research it used qualitative research type by using case study approach. According to Yin (2009) case study is widely used in social sciences research, both in traditional disciplines such as psychology, sociology, political science and anthropology. Case study is also often used as research related to the study of regional planning, public administration, public policy and management science. This study is suitable for use in research where in this research it will answer research question related to good environmental governance synergy through solid limbat processing in coastal area of Gili Ketapang Island.

The place of this research was conducted in Gili Ketapang Island, Sumber Asih Subdistrict, Probolinggo Regency within East Java Province. The research time is April and September 2017. The location of the study was chosen considering the coastal area of Gili Ketapang Island has developed quite rapidly due to the tourism potential such as snorkeling and pilgrimage to Goa Kucing but unfortunately the environment is less clean due to solid waste that accumulate into the attention to do research.

In this research, the technique of sample determination was done by purposive sample by determining randomly. Acquisition of data or information obtained already represented and considered valid from an informant then data has represented all samples to be studied. In this study, the researcher dug information from some communities and fishermen on the island of Gili Ketapang with direct interview technique. Data analysis method used in this research was qualitative data analysis method. This process takes place with the process: (1) recording which generates field notes, then coded to keep the data source traceable; (2) collecting, classifying; (3) thinking, making explanations, searching and finding patterns and relationships, and making general findings. 


\section{Result and Discussion}

\subsection{General explanation of Gili Ketapang Island}

Gili Ketapang Island is a coral island located in the north of Probolinggo regency at coordinates $113015^{\prime} 21$ "east longitude and 7040'48" LS, with typical coastal conditions and residents of the Madurese. length of Gili Ketapang island $\pm 2.1 \mathrm{~km}$ with a width of $\pm 0.6 \mathrm{~km}$, and an area of less than $0.61 \mathrm{~km} 2$. The population of Gili Ketapang Island until 2016 according to Central Statistics Agency data was about 8,680 people. Gili Ketapang Island can be categorized as Small Island, even a very small island with the densest population density in East Java (population density reached 13,095). Gili Ketapang Island has 8 hamlets scattered from west to east of the island of Dusun Pesisir, Mujahidin Hamlet, Krajan Hamlet, Baiturrohman Hamlet, Mardian Hamlet, Gozali Hamlet,

Gili Ketapang Island is located approximately 3.8 nautical miles from the mainland, taken by boat with passengers approximately 45 minutes from the Port of Tanjung Tembaga Probolinggo. This geographical location caused the Gili Ketapang Island to be isolated from the mainland, causing various problems such as limited education, health, accessibility, facilities and infrastructure (electricity, clean water). Such conditions lead to the lack of quality of human resources and environmental damage is increasing. The percentage of people's livelihood in Giliketapang Island, is as follows: fishermen $(90 \%)$; traders $(5 \%)$; laborers (3\%), civil servants $(1 \%)$, others $(1 \%)$.

According to Central Bureau of Statistics Probolinggo (2016), the main livelihood of coastal community of Gili Ketapang Island is fisherman about 4000 inhabitants, 439 traders, 40 industrial workers and 37 civil servants. They live on a dry land area of 61 hectares plus the average temperature on the island of Gili Ketapang between 29 to 30 degrees Celsius thus the rainfall is low. Behind the beauty of the island of Gili Ketapang which currently started to develop as a tourist attraction and for snorkeling activities, there are eye sights that is not great to see when it comes to Goa Kucing. A considerable condition in the region is the limited access and lack of awareness of the cleanliness of the surrounding environment. Not only minimal awareness, people in the region tend to have apathy towards the outside community where they are quite closed with changes. 


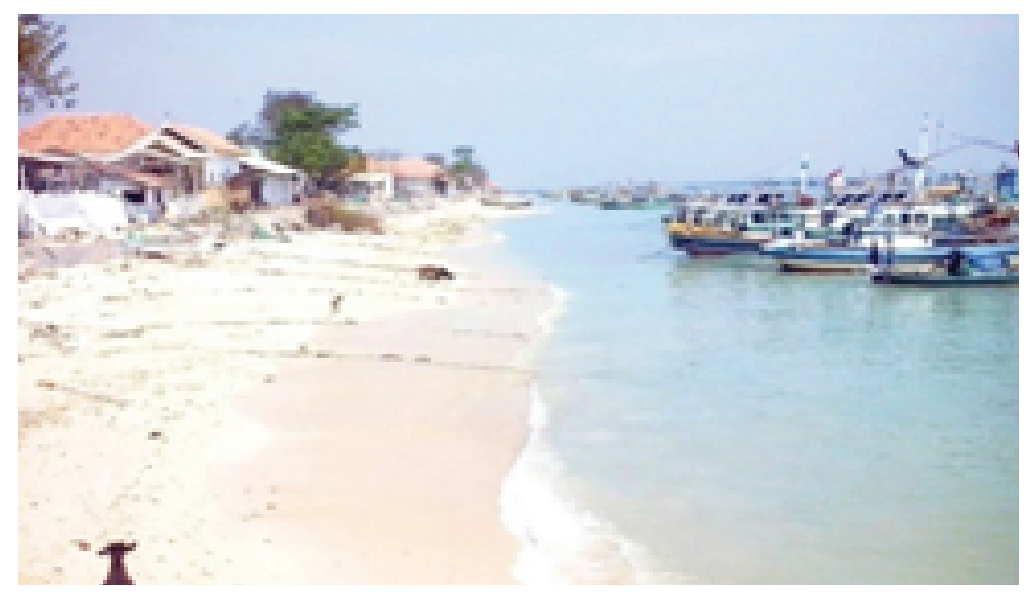

Figure 1: Map of Gili Ketapang Island Probolinggo regency.

\subsection{Good enviromental governance for Gili Ketapang Island}

The principle of good governance according to Prasojo (2008) is basically developed to realize the implementation of better and orderly governance. so far the principles of good governance are more of a jargon developed as part of a paradigm shift of government without being corroborated by pouring these principles into the legislature as the norm of concrete law. Without stipulation in the legislation, the principles of good governance do not provide the binding force for government officials to comply with and do not impose a force for government officials to carry it out.

The implementation of governance based on the principles of good environmental governance means that the management of government affairs in the field of natural resources and environment is organized in such a way that based on the vision of protection and preservation of environmental functions in supporting the implementation of sustainable development [3]. A good government that cares about environmental sustainability is a government that applies the principles of good governance and good environmental governance).

Law No. 32 of 2009 on Environmental Protection and Management article 65 paragraph (1) states: "Everyone has the right to a good and healthy environment as a part of human rights." In addition to Article 67 of the Act stating: "Every person has the obligation to preserve the function of the environment and to control pollution and / or environmental damage". This means that between the community and the government needs to establish a good relationship in preserving the environment. 
In the introduction of governance, the writer describes how good environmental governance in which in good environmental management there is some cooperation between the government, non-government (private) and the community that can be synergized with the innovation of solid waste disposal that began to disturb the environment of Gili Ketapang Island. The coastal environment of the island of Gili Ketapang that still feels still not good, resulting in the island is not perfect in environmental settings. The role of Probolinggo Regency Government towards this coastal area has been quite helpful starting with the construction of Mayangan pier for economic activities of the community and the port as a place of ship traffic to the small island. The government cannot work alone, it is necessary cooperation with other parties to build the coastal area is more advanced in the field of tourism, economy, education, natural resources and most importantly is the environmental management in the area.

The limitations of Probolinggo regency government to the coastal area of Gili Ketapang Island is still lacking, given the limited power, distance and travel time is quite far from the reach of the Government. Problems of handling the environment themselves, especially in the management of solid waste such as plastic waste, wood, heavy metals, baby diapers, bottles, broken glass and so drift into the sea water can result as air pollution due to sea water contamination. Often coastal management does not base on good environmental governance principles as well as: (1) participation, (2) law enforcement, (3) transparency, (4) equality, (5) responsiveness, (6) insights (9) efficient and effective, (10) professionalism. Good Enviromental Governance is necessary for coastal development to run maximally not only the role of Government but public awareness is needed for Gili Ketapang Island more developed and can increase the source of income from marine tourism and religious tourism with collaboration.

In Figures 2 and 3 two of the describe the activities of the people of Gili Ketapang Island, who mostly work as fishermen and Muslims who still have a level of awareness of their environmental degradation. There should be cooperation between the government, community leaders and other stakeholders in the region to assist in the development of the coastal area of Gili Ketapang Island for cleaner, technological literacy as there is assistance from tiuggi university and become a source of income.Berkiblat in Japan where as a country with waste management which explains well that the waste is done by filtering and sorting both organic and non organic waste, it aims to create a cleaner environment. 


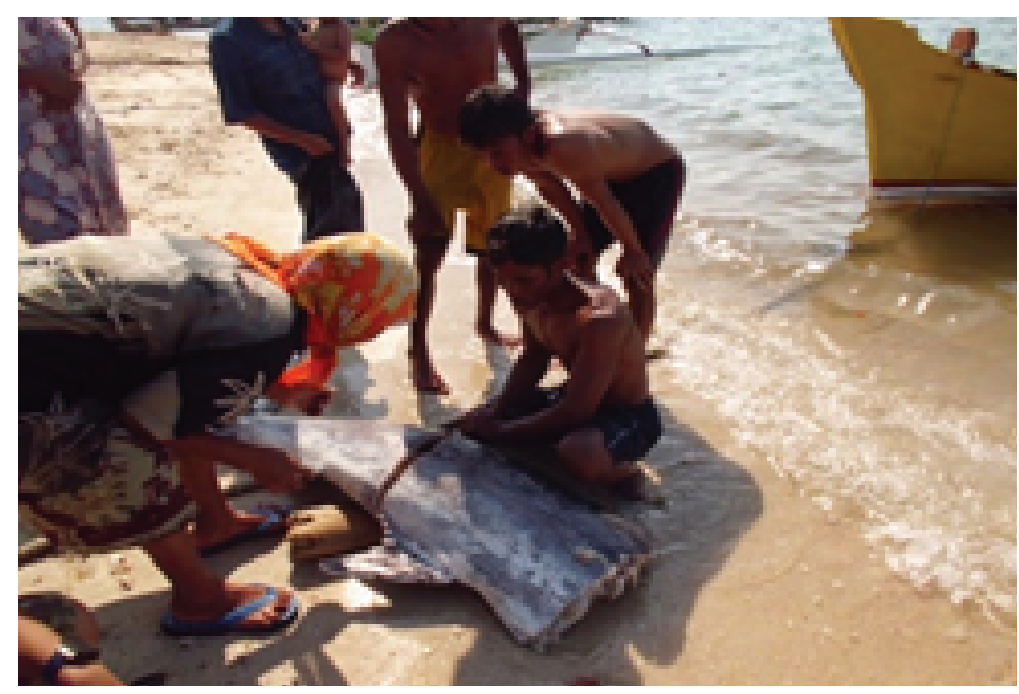

Figure 2: Fishermen's Activities.

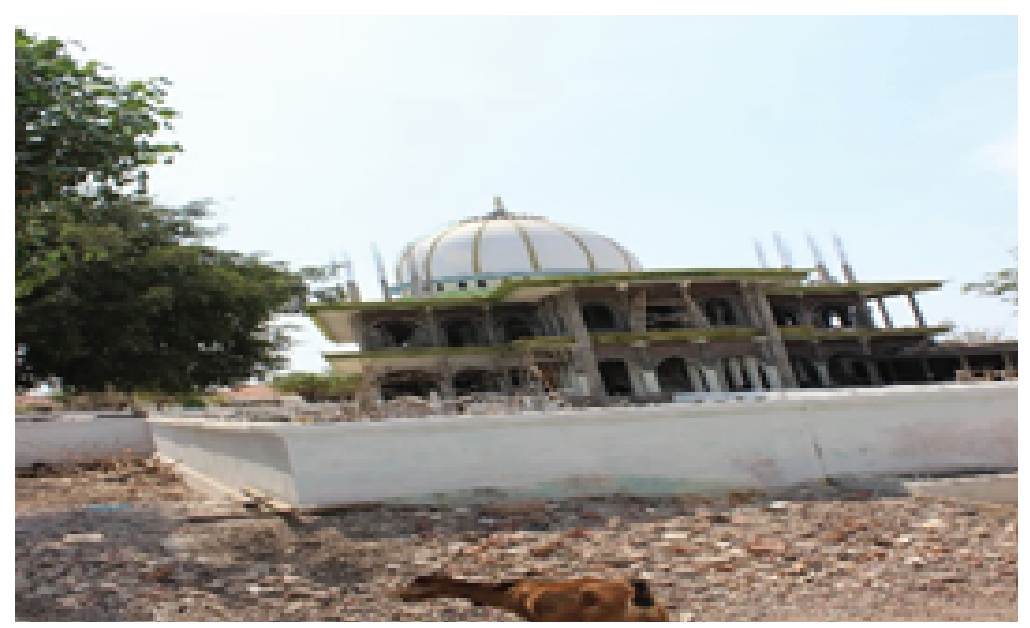

Figure 3: Neighborhood around the mosque.

Based on the Regulation of the Minister of Marine Affairs and Fisheries of the Republic of Indonesia Number 40 / Permen-Kp / 2014 on the role and empowerment of communities in the management of coastal areas and small islands of coastal and small island management or called PWP-3-K it is necessary to coordinate the planning, utilization, and control of coastal and small island-island resources undertaken by the Government and Government of the Region, between sectors, between terrestrial and marine ecosystems, and between science and management to improve people's welfare.

Some activities that can be synergized to increase awareness of environmental hazards if solid waste management is not handled seriously by the people of Gili Ketapang Island, it can be done:

1. Governments and local governments are required to: 
(a) set the target of waste reduction gradually over a period of time

(b) facilitate the adoption of environmentally friendly technologies

(c) facilitate the application of environmentally friendly label products

(d) facilitate recycling and recycling activities

(e) facilitate the marketing of recycled products.

2. Business actors in carrying out activities using production materials that cause as little as possible, can be reused, recyclable, and / or easily decomposed by natural processes.

3. Communities in carrying out waste reduction activities using materials that can be redeployed, recycled, and / or easily decomposed by natural processes

4. The Government provides:

(a) incentives to everyone who does waste reduction

(b) a disincentive to anyone who does not reduce waste

The above provisions still need to be further regulated in the form of Government Regulation or Regional Regulation of Probolinggo Regency in order to be executed properly and on target. Not only is the Government, the role of a pro-active community also very necessary for all programs can be realized perfectly.

\subsection{Minimization of solid waste on Gili Ketapang Island}

Several approaches can be taken to control or reduce solid waste for the coastal areas of Gili Ketapang Island, among others:

1. A proactive approach: the effort to ensure that the material use process will be minimally wasteable, with the lowest possible level of danger.

The proactive approach is a strategy introduced in the late 1970s in the industrial world, known as a clean process or clean technology that targets control or reduction of waste through the use of cleaner and more environmentally friendly technologies. This concept simply includes:

(a) Better regulation in the management of material use and energy and waste through good house keeping

(b) Savings of raw materials, fluids and energy used 
(c) The use of scattered raw materials that can still be utilized

(d) Replacement of raw materials, fluids and enemas

(e) Modification of the process even if the replacement process and technology used for emissions or waste generated to a minimum and with the lowest possible level of hazard

(f) Separation of waste formed by type to make it easier to handle

2. Reactive approach: ie waste handling done after the waste is formed

The reactive approach, which is a concept deemed to be improved, is a concept with control efforts made after the waste is formed, known as the end-of-pipe approach.

This concept relies on waste processing and waste management technologies, in order for the emissions and residues produced to be safely released back into the environment. The concept of reactive waste control is then improved through reuse, and / or through a process prior to recycling of the waste.

In general minimizing solid waste in the coastal area of Gili Ketapang Island can be done with priority activities focus on handling waste among others:

1. Step 1 Reduce (restriction): to make the waste produced as little as possible

2. Step 2 Reuse: When the waste is finally formed, then try to use the waste directly

3. Step 3 Recycle: residual or waste that is left or cannot be used directly, then processed or processed for use, either as a substance or as a source of energy.

4. Step 4 Treatment: residue produced or which cannot be utilized then processed, in order to facilitate the next handling, or to be safely released in the environment

5. Step 5 Dispose: residues / waste that cannot be processed need to be released into the environment safely, namely through good engineering and safe as to get rid of a landfill designed and prepared well

6. Step 6 Remediation: environmental media (especially water and soil media) that has been contaminated by waste that is not well managed, needs to be rehabilitated or repaired through appropriate engineering upgrades, such as bioremediation and so on.

Applying Sound Material Concept - Cycle Society from Japan (https://www.env.go. $\mathrm{jp} /$ ): 
The concept of Sound Material - Cycle is defined as a society in which the consumption of natural resources will be preserved and the environmental burden will be reduced as much as possible, by preventing or reducing waste generation, from products, etc. by promoting the use of appropriate cyclical products. When this product, it has become a circular resource, and by ensuring proper circular source removal is not included in cyclical usage (eg, disposal as waste, with "waste")

The Sound Material-Cycle Society concept thus helps ensure a healthy and cultured life for the present and future generations of the nation, articulating the basic principles of the formation of the Sound Material-Cycle Society, in accordance with the basic philosophy of the Environmental Act (Law No. 91 of 1993), clarifying the responsibilities of States, local governments, business actors and citizens, and articulating the fundamentals to establish a Sound Material-Cycle Society establishment policy, including to establish a basic plan for building Sound Material-Cycle Society.

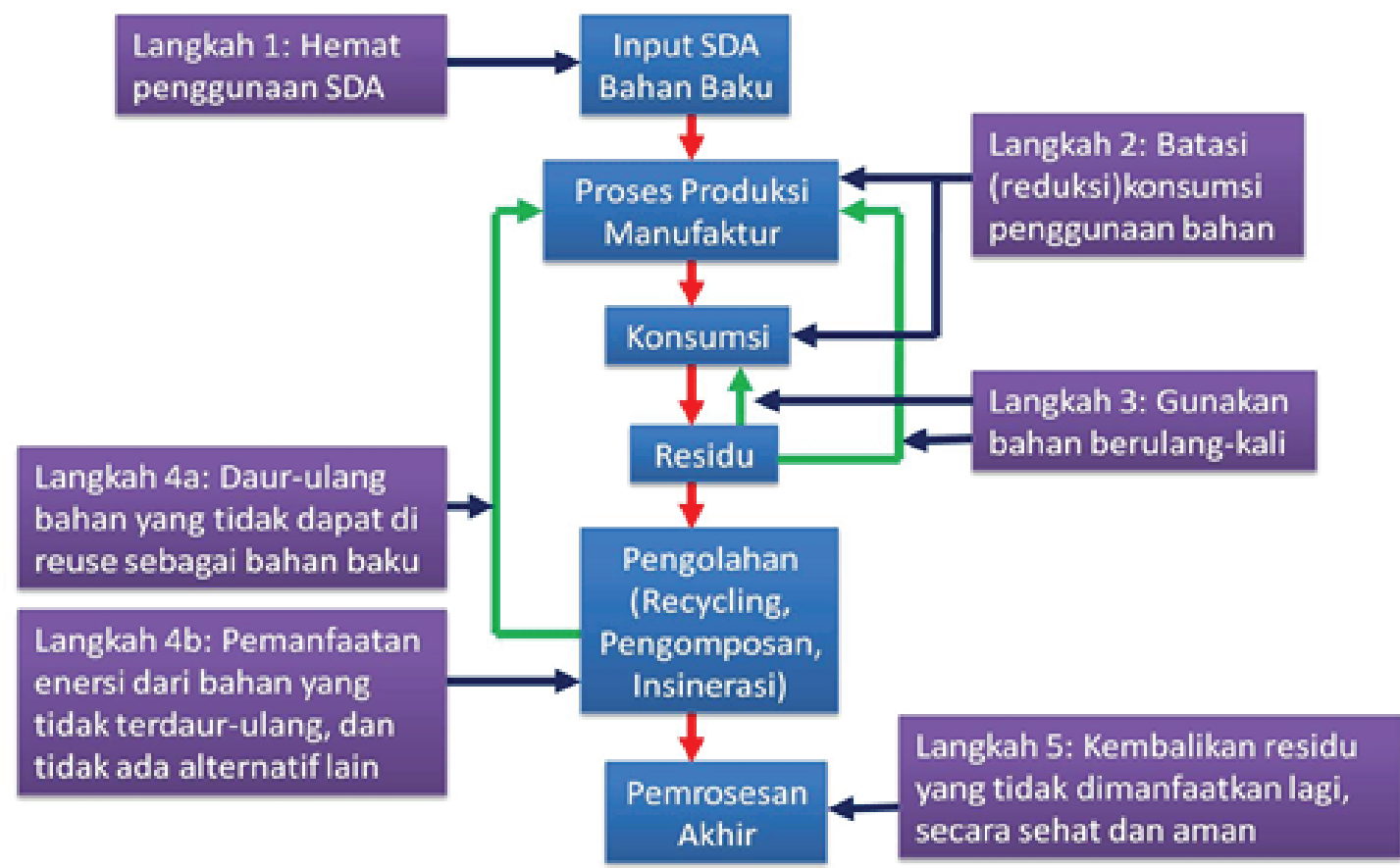

Figure 4: Concept of Sound Material- Cycle Society.

1. Step 1: Savings on the use of natural resources

2. Step 2: Limit consumption of the use of materials in daily activities, including in the production process in an industry

3. Step 3: Use of consumed products over and over again

4. Step 4a: Recycling materials that cannot be used directly 
5. Step 4b: Utilization of energy contained in waste, which is usually done through incineration technology

6. Step 5: Return of residues or waste that cannot be utilized again through natural disposal safely and healthily

In order to apply the concept of Sound Material-Cycle Societydibutuhkan community participation through the concern and involvement of the community physically or non-physically, directly or indirectly, on the basis of self-awareness or as a result of the role of guidance in the management of coastal areas of Gili Ketapang. Below is picture 5 and 6 showing a form of awareness shown by community in coastal area of Gili Ketapang island:

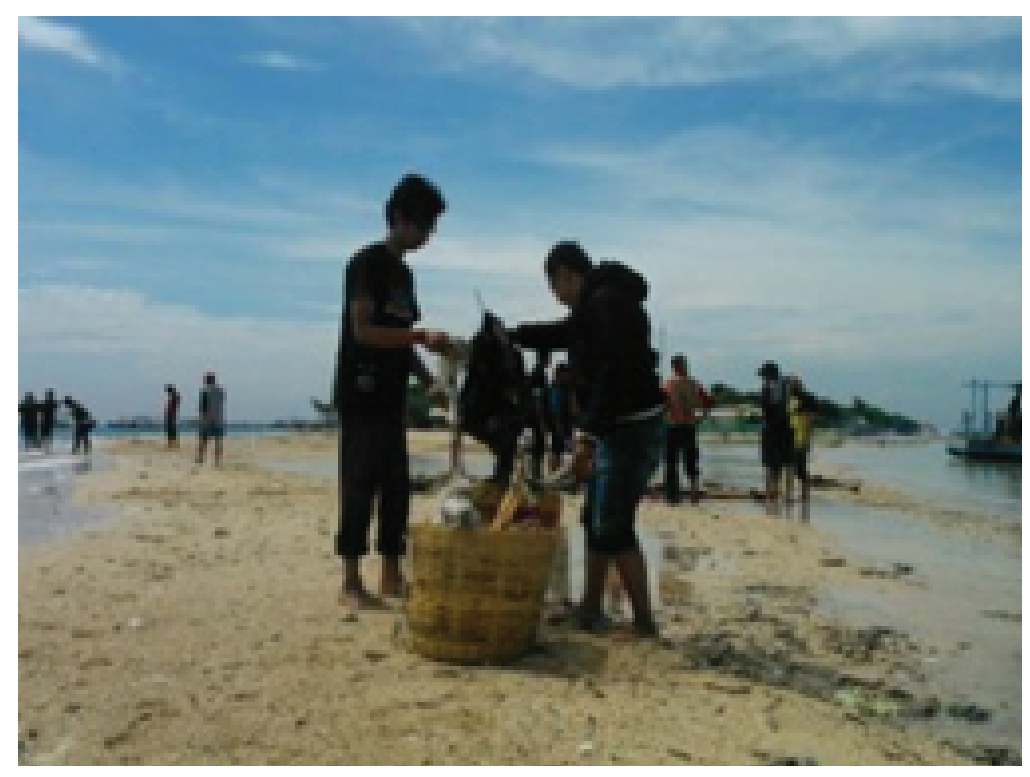

Figure 5: Waste Collection.

According to Law No. 18 of 2008 on Waste Management, the main priority that must be done by all parties is how to reduce waste as much as possible. The waste or residue part of the remaining waste reduction activities is then processed (treatment) as well as landfilling. To reduce the waste is required role of government.

If we make comparisons that build a culture to maintain cleanliness of the waste can be imitated by the people of Indonesia as in Japan such as (1) high awareness of the importance of garbage management, (2) success in building shame in the community and planting into the natural (3) education is done massively and aggressively early on through teaching and training how to sort the waste according to its type 


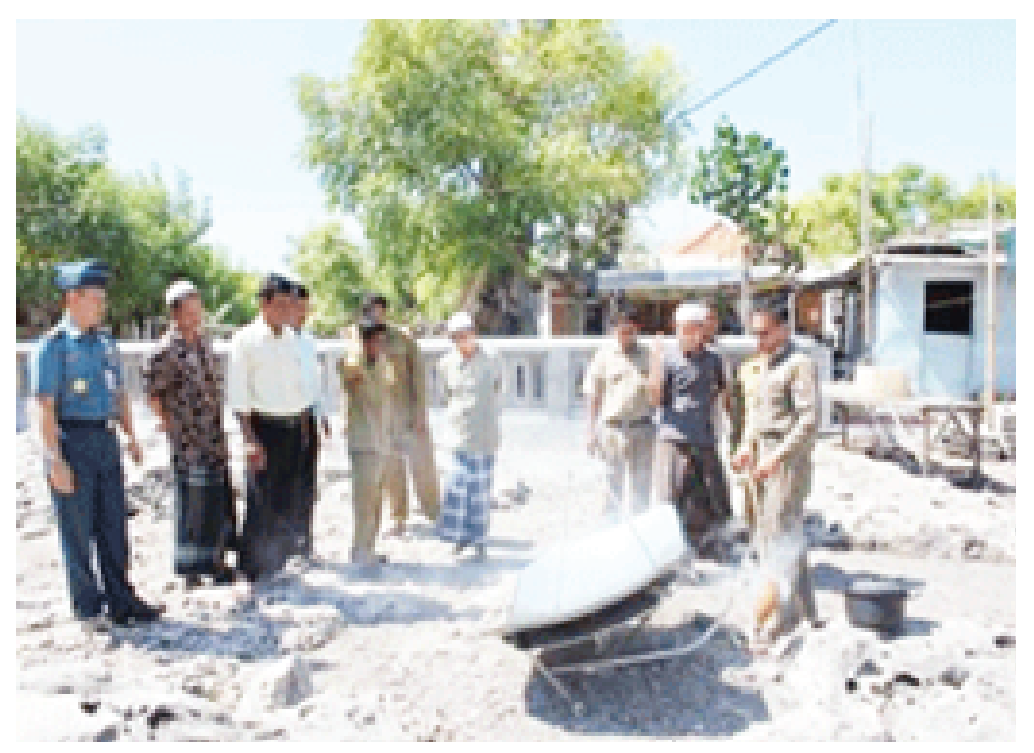

Figure 6: Development of Solar energy.

As a comparison, in Japan dividing the responsibility to the stakeholders on the waste management, especially solid waste, which always increase volume every day in the coastal area of Gili Ketapang Island, the role of each stakeholder, among others:

1. Waste-producing society:

(a) Understand the impact of waste generated

(b) Reconsider their lifestyle

(c) Choose goods and services that are environmentally sound

(d) Participate actively in waste management, such as waste segregation

(e) Participate in the development of $3 R$ based waste management

2. Non-Governmental Organization:

(a) Promote positive $3 R$ activities at the community level

(b) Promote awareness raising

(c) Prepare-conduct training and socialization

(d) Monitor efforts by business and government activities

(e) Provide appropriate policy input

3. Fihak Swasta:

(a) Prepare environmentally sound goods and services

(b) Carry out 'take-back' activities, reuse and recycle of used products 
(c) Managing waste in an environmentally sound manner

(d) Develop an environmental management system

(e) Providing honest information to consumers through labels and reports.

4. Local Government:

(a) Ensure the implementation of rules and guidelines

(b) Prepare action plan by realizing Rubbish Bank (Rubbish Care)

(c) Encouraging 'green purchasing', and increasing community understanding

(d) Ensure the public to participate in the decision-making process

(e) Act as a facilitator in $3 R$ and business activities

(f) Act as a local coordinator in community-oriented development of materials

(g) Providing space and opportunities to exchange goods and information amongst stakeholders

(h) Promotion of international cooperation

5. Central Government:

(a) Develop a system, including the legal aspects required

(b) Provide subsidies and tax arrangements for facilities, research and development to build a material-minded society

(c) Provide encouragement and confirmation to residents and NGOs who will carry out voluntary activities

(d) Prepare the basics needed for the activities of all stakeholders

(e) Promote international cooperation and dialogue related to $3 \mathrm{R}$ activities

Solid waste processing in the coastal area of Gili Ketapang Island should be handled seriously to reduce environmental pollution both in the air and sea water due to low public awareness. It is time for the government and local communities and community organizations to be actively involved and directly protect the natural resources that have many uses. Communities who have direct contact with the natural surroundings should be given the understanding and education in a more massive way about the preservation and management of the surrounding environment. The significance of this is to preserve nature for future generations. The involvement of local communities, community leaders and community organizations is expected to overcome the problem of solid waste on the coast of Gili Ketapang Island. 


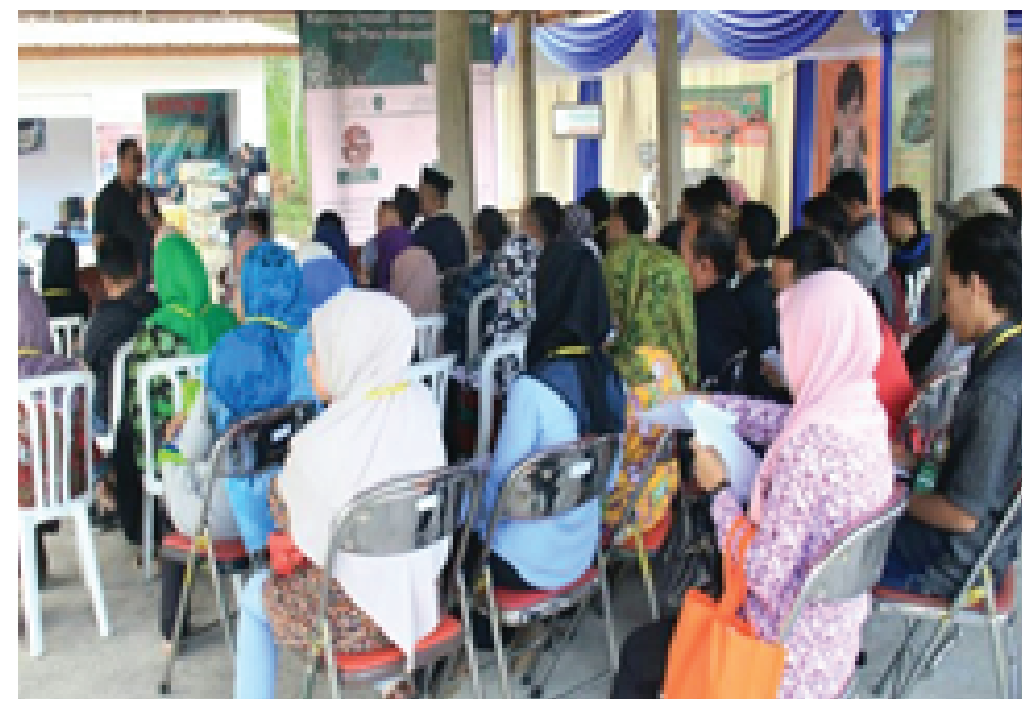

Figure 7: Socialization from the Government.

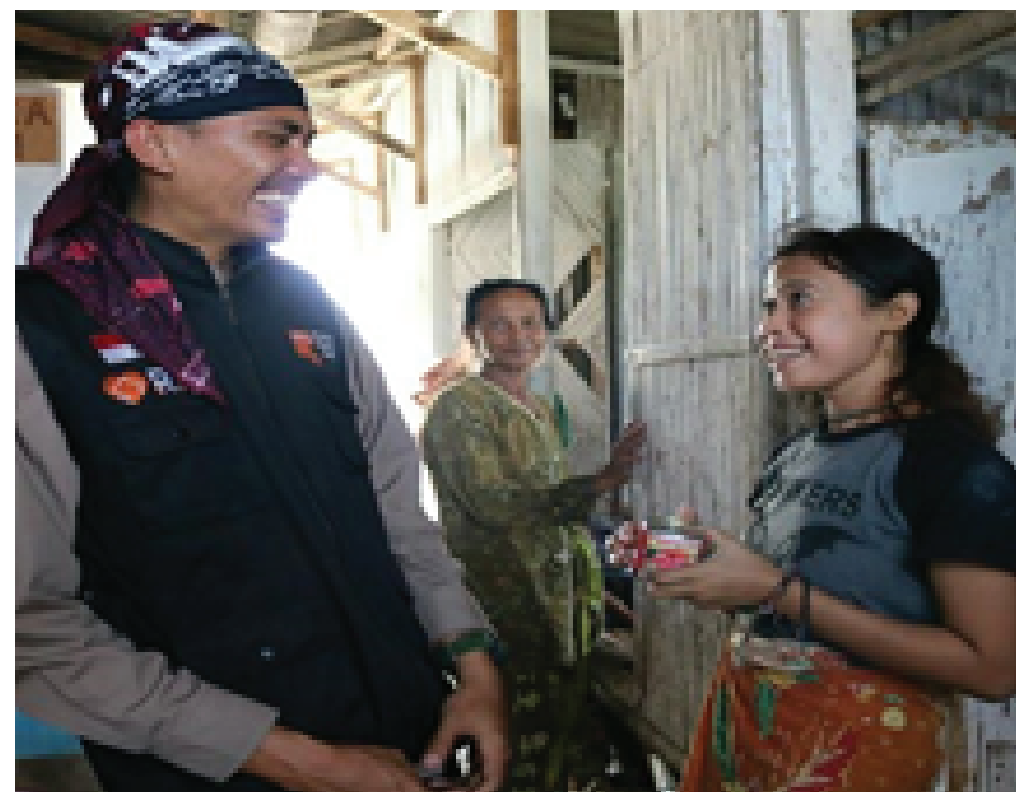

Figure 8: Role of Volunteers.

Preventive efforts prior to repressive efforts in dealing with environmental issues are needed with careful planning with inter-agency coordination such as the Central Government and Local Government. In addition, community participation also plays an important role in minimizing criminal (crimes) in the field of environment, such as pollution, logging, destruction of nature and so on

\section{Conclusions, Implications and Conditions}




\subsection{Conclusion}

A good government that cares about environmental sustainability is a government that implements good governance principles and good environmental governance principles. The coastal environment of Gili Ketapang is still not good, causing the island to be imperfect in environmental setting. Coastal management should outline the principles of good environmental governance as well as: (1) participation, (2) law enforcement, (3) transparency, (4) equality, (5)) responsiveness, (6) forward insight, (7) accountability, (8) supervision, (9) efficient and effective, (10) professionalism. By using the principle (good environmental governance) is expected to improve the environmental quality of the people of Gili Ketapang Island.

The principle of good environmental governance combined with the concept of Sound Material-Cycle Society clarify the responsibilities of the Country, local governments, business actors and citizens, and articulate the basic things to make policy formation Sound Material-cycle Society.

\subsection{Implication}

The implication of this research is to reduce the problem of the lack of waste management maximally then the steps that can be done to reduce the volume of solid waste is by Reduce (restriction), Reuse, Recycle, Treatment (process), Dispose and Remediation. How it can be done with rubbish bank, rubbish care, provide education about waste recycling process and carry out the activities of 'take-back', the re-use and recycling of used products. Participation of the community through the concern and involvement of the community physically or non-physically, directly or indirectly, on the basis of self-awareness so that every step that has been planned can be applied perfectly. Solid waste management is expected to create a clean and orderly environment so that coastal life can be more healthy and beautiful.

\subsection{Limitations}

This research only explains the problems that exist in Gili Ketapang Island Probolinggo by utilizing the concept of good environmental governance with qualitative approach method. 


\section{References}

[1] http://lipi.go.id/siaranpress/pembangunan-inklusif-masyarakat- diwilayahpesisir-indonesia/13704 / Diakses 08 Oktober 2017

[2] https://probolinggokab.bps.go.id/website/pdf_publikasi/KecamatanSumberasih-Dalam-Angka-2017.pdf/ Diakses 10 Oktober 2017

[3] Marsudi Triatmodjo, S. H. (2008). Penerapan prinsip good environmental governance dalam kebijakan daerah bidang sumber daya alam dan lingkungan hidup di Kabupaten Sleman (Doctoral dissertation, Universitos Gadjah Mada).

[4] Peraturan Menteri Kelautan Dan Perikanan Republik IndonesiaNomor 40/PermenKp/2014TentangPeran Serta Dan Pemberdayaan Masyarakat Dalam PengelolaanWilayah Pesisir Dan Pulau-Pulau Keci

[5] Prasojo, Eko. Reformasi Pertama Birokrasi, Artikel, Kompas, Edisi 2 April 2008.

[6] Purwo Santoso. (2008)Environmental Governance: Filosofi Alternatif Untuk Berdamai Dengan Lingkungan Hidup. Universitas Gajah Mada

[7] Undang-Undang Nomor 18 Tahun 2008 tentang Pengelolaan Sampah UndangUndang Nomor 32 Tahun 2009 Tentang Perlindungan dan Pengelolaan Lingkungan Hidup

[8] United Nations. United Nations Convention on The Law of The Sea. 10 December 1982.

[9] Yin, Robert, K. (2009). Studi Kasus Desain dan Metode. Jakarta: Rajawali Pers

[10] https://www.env.go.jp/en/laws/recycle/12.pdf / Diakses 18 Oktober 2017 